\title{
Needs Analysis of Chinese Chemical Engineering and Technology Undergraduate Students in Yangtze University in English for Specific Purposes
}

\author{
Jianrong $\mathrm{Wu}$, Yougen Lou* \\ School of Foreign Studies, Yangtze University, Jingzhou, China \\ Email: *louyougen@163.com
}

How to cite this paper: $\mathrm{Wu}, \mathrm{J}$. R., \& Lou, Y. G. (2018). Needs Analysis of Chinese Chemical Engineering and Technology Undergraduate Students in Yangtze University in English for Specific Purposes. Creative Education, 9, 2592-2603. https://doi.org/10.4236/ce.2018.915195

Received: October 30, 2018

Accepted: November 19, 2018

Published: November 22, 2018

Copyright (๑) 2018 by authors and Scientific Research Publishing Inc. This work is licensed under the Creative Commons Attribution International License (CC BY 4.0).

http://creativecommons.org/licenses/by/4.0/

(c) (i) Open Access

\begin{abstract}
English for Specific Purposes (or ESP) is as a part of college English. This paper aims to investigate Chinese chemical engineering and technology undergraduate students' needs in English for Specific Purposes (ESP). Eighty first-year chemical engineering and technology undergraduate students from Yangtze university as volunteer participates were in this study to answer the questionnaires about their needs in ESP and 60 volunteer participants were interviewed to provide their responses on ESP. All the data from questionnaires students answered and the interviews were collected. All the data were analyzed by SPSS 17 . The results showed that: 1) The chemical engineering and technology undergraduate students' level of proficiency in the language skills was medium; 2) The students ranked the language skills (listening and speaking) as the most important language skills; 3) Understanding instructions, following question/answer sessions, answering the questions, reading field-related textbooks, instructions for assignments, taking notes in lectures were more emphasized by the students in ESP classes; 4) The students had positive responses on the needs in ESP. Forty eight (80\%) students thought that ESP would be better for their English learning and major study and thirty two (53.3\%) students thought reading as the most important language skill ESP. Findings in the present study could be provided as implications for course designers and recommendations for future studies.
\end{abstract}

\section{Keywords}

Chemical Engineering and Technology, Undergraduate Students, Needs Analysis, English for Specific Purposes 


\section{Introduction}

College English is required for college students in colleges and universities in mainland China. College English in mainland China can be divided into three parts: General English (GE), English for Specific Purposes (ESP) and cross-culture communication. In 2013, many English for Academic Purposes (EAP) courses were taught in many key universities (such as Fudan University, Shanghai Jiaotong University) in Shanghai China. Then ESP courses (including EAP and English for Occupational Purposes or EOP) were taught in other universities in mainland China. ESP is focused on English learning and teaching situation, in which teaching methods and learning environment are different from General English (Rahman, 2015). EAP courses are accepted by more undergraduate students in key universities in Shanghai, China, but are ESP courses needed by first-year non-English-majored undergraduate students in local colleges or universities? We want to look for the answer in this study to the question.

\section{Literature Review}

\subsection{Definition of Needs Analysis}

There were different definitions for the term "needs analysis". The term, "analysis of needs" first appeared in the 1920's in the West Bengal, a province of India when Michael West introduced the concept of "needs" to cover what learners will be required to do with the foreign language in the target situation and how learners might best master the language during the period learning (Rahman, 2015: p. 25). Hutchinson and Waters (1987) define needs as necessities, wants and lacks. Brindley (1989: p. 56) describes it as "the gap between what the learners' actual needs are and what should be taught to them". Analysis is essentially seen as the exploration process of communicative tasks, that is, what the learners need to do with the target language (Al-Otibi, 1994).

\subsection{Components of ESP Needs Analysis}

ESP needs analysis could be classified as Target Situation Analysis (TSA), Learning Situation Analysis (LSA), Present Situation Analysis (PSA), mean analysis and language audits are the fundamental components for assessing language needs of learners (Rahman, 2015: p. 26).

Target Situation Analysis (TSA) centers on identifying the learners' language requirements in the occupational or academic setting, "The earliest TSA procedures were designed to determine 'how much English' was used” (West, 1994). Robinson (1991: p. 8) said that "a needs analysis, which focuses on students' needs at the end of a language course, can be called a TSA (Target Situation Analysis)". Dudley-Evans \& St. John (1998: p. 124) defined TSA as, "TSA refers to task and activities learners are/will be using English for target situation".

Learning Situation Analysis (LSA), referred to subjective, felt and process-oriented needs, was effective ways of learning the skills and language (Dudley-Evans \& St. John, 1998). Dudley-Evans \& St. John (1998: p. 124) stated 
that Present Situation Analysis (PSA) estimated strengths and weaknesses in language, skills and learning experiences.

Means analysis directed the environment in which a course would be run or the environment in which a project would take root, grow healthily and survive (Dudley-Evans \& St. John, 1998).

"Language audits, large-scale research in examining language needs, are executed for companies, regions or countries" (Jordan, 1997).

There were many scholars gave their ideas to the term "needs analysis". Strevens (1980) thought that needs analysis was a necessary first step for specific purposes language teaching; it is more concerned with the nature of scientific discourse._Hutchinson and Waters (1987) argued, "any language course should be based on needs analysis". Robinson (1991) thought of needs analysis as "needs analysis is generally regarded as critical to ESP, although ESP is by no means the only educational enterprise which makes use of it".

\subsection{Studies on Needs Analysis}

Many scholars in the world did their researches on needs analysis in ESP. In China, there were scholars' studies on needs analysis in ESP (Luo \& Chen, 2012; Li, 2014; Wang, 2014; Yu \& Fu, 2015; Zhen et al., 2015; Ye, 2018).

In other countries, there were scholars' studies on needs analysis in ESP (Eslami, 2010; Solak, 2012; Rahman, 2015; Mohammed, 2016; Alsamadani, 2017; Nafissi et al., 2017; Mohammed \& Nur, 2018).

From the literature above, we can find that few studies were done on needs analysis of Chinese chemical engineering and technology first year non-English-majored undergraduates in English for Specific Purposes. We wanted to investigate the needs of first year Chinese chemical engineering and technology undergraduates in English for Specific Purposes.

The present study was designed to answer the following research questions:

1) What is the English language proficiency of non-English-majored undergraduate students?

2) What are ranks of the language skills emphasized in ESP classes for non-English-majored undergraduate students?

3) What are the language skills and activities much emphasized in ESP classes for non-English-majored undergraduate students?

4) What are interview responses from non-English-majored undergraduate students on the needs in ESP?

\section{Methodology and Data Collection}

\subsection{Participants}

Eighty first-year chemical engineering and technology Non-English-majored undergraduate students from Yangtze University were volunteers in this study. Eighty freshmen (48 male participants and 32 female participants) were taught by the same female instructor, their average age 18, Chinese as their first or mother language. They had similar level of education background, family back- 
ground, personality and life experiences, which was to say, their overall learning and cognitive abilities were almost equal.

\subsection{Instruments}

The instruments utilized in this study were questionnaires and interviews.

Questionnaire. The questionnaire used in this study to gain responses from chemical engineering and technology non-English-majored undergraduate students in ESP needs was from revised Alsamadani's (2017) questionnaire. The questionnaire included two parts: background and language needs, total 26 questions. Part one: background included personal information (name, age and field of study) and four questions ( 1 - 4) for the level of language skills' or components' (listening, speaking, reading and writing)proficiency based on a five-likert scale (1) excellent, 2) very good, 3) good, 4) fair, and 5) poor). Part two: language needs included general information (question 5 - 9) on language needs (listening, speaking, reading, writing and grammar) and detailed information (question 10 - 26) on language skills' needs (listening skills (question 10 13), speaking skills (question 14 - 18), reading skills (question 19 - 22), writing skills (question 23 - 26)) based on a five-likert scale (1) very important, 2) important, 3) not important, 4) not applicable, and 5) applicable).

Interviews. In order to gain more information of chemical engineering and technology undergraduate students' needs in ESP, interviews were used in this study after questionnaires answered by the students. 60 volunteer students were invited to attend the interviews about their language skills' needs (listening, speaking, reading and writing) in ESP to answer the following two questions: 1) Do you think that which one (General English and English for Specific Purposes) will be better for you to improve your English learning and major study? Why? 2) Do you think that which language skills' needs (listening, speaking, reading and writing) in ESP is the most important for your English learning and major study? Why?

\subsection{Data Collection and Analysis}

Eighty copies of questionnaires were distributed to the participants to answer in 20 minutes in the class. The first author in this study explained how to answer the questions in the questionnaire before students answered the questionnaires. After 20 minutes, all the 80 copies of questionnaires were collected. All the data from the 80 questionnaires were input into SPSS17.0 to be processed and analyzed. Among 80 questionnaires, 3 questionnaires (blank) were not used in this

study. Tools in SPSS17.0 such as Mean and T-test were used in this study to analyze the data we collected.

\section{Results}

\subsection{Results of Levels of the Students' English Language Skills Proficiency}

Table 1 showed the levels of proficiency in language skills or components of the 
participants. Among levels of proficiency in language skills or components of the participants, the orders were Reading $(\mathrm{M}=3.247, \mathrm{SD}=.652)$, Speaking $(\mathrm{M}=$ $3.507, \mathrm{SD}=.788)$, Listening $(\mathrm{M}=3.558, \mathrm{SD}=.910)$, Writing $(\mathrm{M}=3.766, \mathrm{SD}$ $=.793$ ). The levels of proficiency in language skills or components of the participants were medium. And the level of proficiency of the participants in reading $(\mathrm{M}=3.247, \mathrm{SD}=.652)$ was more close to good (3), the students' level of proficiency in writing $(\mathrm{M}=3.766, \mathrm{SD}=.793)$ was more close to fair (4).

\subsection{Results of Students' Ranks on the Language Skills and Components Emphasized in ESP Classes}

Table 2 showed results of the participants' ranks on the language skills and components emphasized in ESP classes. All the language skills and components in ESP classes were emphasized by participants. The orders of the participants' ranks on the language skills and components much emphasized in ESP classes were Listening $(\mathrm{M}=1.117, \mathrm{SD}=.537)$, Speaking $(\mathrm{M}=1.117, \mathrm{SD}=.458)$, Writing $(\mathrm{M}=1.156, \mathrm{SD}=.488)$, Reading $(\mathrm{M}=1.182, \mathrm{SD}=.601)$, Grammar $(\mathrm{M}=1.896$, $\mathrm{SD}=.736$ ). The language skills (listening and speaking) were most emphasized by the participants.

\subsection{Results of the Students' Language Skills and Activities Emphasized in ESP Classes}

Table 3 showed results of the participants' language skills and activities emphasized in ESP classes. From question 10 to question 26, except question 24 and question 26, all the language skills and activities in ESP classes were emphasized by the participants. Listening part (question 10 - question 13), "Understanding instructions" was ranked as the first important activity, "Following question/answer sessions" as the second. Speaking part (question 14 - question 18), "Answering the questions" was ranked as the first, "Giving oral presentations" as the second. Reading part (question 19 - question 22), "Field-related textbooks" was ranked as the first, "Instructions for assignments" as the second. Writing part (question 23 - question 26), "Taking notes in lectures" was ranked as the first, "Assignments and homework" as the second.

\subsection{Results of Interviews from Students' Responses on Needs of ESP}

From 14:00 to 15:00 October 25, 2018, 60 volunteer students were invited to attend the interviews about their language skills' needs (listening, speaking, reading and writing) in ESP to answer the following two questions: 1) Do you think that which one (General English and English for Specific Purposes) will be better for you to improve your English learning and major study? Why? 2) Do you think that which language skills' needs (listening, speaking, reading and writing) in ESP is the most important for your English learning and major study? Why?

For Question 1), 48 students ( $80 \%$ of 60 students) said that ESP would be better for them to improve their English learning and major study because they 
Table 1. Results of level of proficiency on language skills.

\begin{tabular}{lcc}
\hline & $\mathrm{M}$ & $\mathrm{SD}$ \\
\hline Listening & 3.558 & .910 \\
Speaking & 3.507 & .788 \\
Reading & 3.247 & .652 \\
Writing & 3.766 & .793 \\
\hline
\end{tabular}

Table 2. Results of students' ranks on the language skills.

\begin{tabular}{lll}
\hline & M & SD \\
\hline How important is listening skill? & 1.117 & .537 \\
How important is speaking skill? & 1.117 & .458 \\
How important is reading skill? & 1.182 & .601 \\
How important is writing skill? & 1.156 & .488 \\
How important is grammar? & 1.896 & .736 \\
\hline
\end{tabular}

Table 3. Results of the students' language skills and activities in ESP classes.

\begin{tabular}{|c|c|c|}
\hline & M & $\mathrm{SD}$ \\
\hline \multicolumn{3}{|l|}{ Listening } \\
\hline Question 10 & 1.909 & .518 \\
\hline Question 11 & 1.208 & .592 \\
\hline Question 12 & 1.247 & .542 \\
\hline Question 13 & 1.831 & .548 \\
\hline \multicolumn{3}{|l|}{ Speaking } \\
\hline Question 14 & 1.299 & .796 \\
\hline Question 15 & 1.753 & .652 \\
\hline Question 16 & 1.221 & .661 \\
\hline Question 17 & 1.247 & .728 \\
\hline Question 18 & 1.831 & .497 \\
\hline \multicolumn{3}{|l|}{ Reading } \\
\hline Question 19 & 1.156 & .592 \\
\hline Question 20 & 1.987 & .525 \\
\hline Question 21 & 1.844 & .515 \\
\hline Question 22 & 1.208 & .515 \\
\hline \multicolumn{3}{|l|}{ Writing } \\
\hline Question 23 & 1.221 & .576 \\
\hline Question 24 & 2.494 & .837 \\
\hline Question 25 & 1.935 & .592 \\
\hline Question 26 & 2.091 & .672 \\
\hline
\end{tabular}

could use English as the tool to learn and study English and their major (chemical engineering and technology); the knowledge of chemical engineering and technology was seldom included in the General English. Ten students $(16.7 \%$ of 60 students) said that they did not have ideas on which one (General English and English for Specific Purposes) better for them in English learning and major study because they did not learn or study ESP classes. 
For Question 2), 60 students thought that all language skills (listening, speaking, reading and writing) in ESP were needed; thirty two students (53.3\% of 60 students) thought the language skill (reading) as the most important language skill for them because they could read ESP books to learn English and study their major; fourteen students ( $23.3 \%$ of 60 students) thought the language skill (writing) as the most important for them because they wanted to write academic papers in English; fourteen students (23.3\% of 60 students) thought the language skill (listening) as the most important for them because they needed to understand the ESP instructors in ESP classes.

\section{Discussion}

The authors in this study want to investigate the answers to the four questions. Question 1: What is the English language proficiency of chemical engineering and technology undergraduate students? Question 2: What are ranks of the language skills much emphasized in ESP classes for chemical engineering and technology undergraduate students? Question 3: What are the language skills and activities much emphasized in ESP classes for chemical engineering and technology undergraduate students? Question 4: What are interview responses from non-English-majored undergraduate students on the needs in ESP?

For Question 1, from Table 1, we could know that levels of proficiency in language skills or components of the participants were medium. And level of proficiency of the participants in reading $(\mathrm{M}=3.247, \mathrm{SD}=.652)$ was more close to good (3), the students' level of proficiency in writing $(\mathrm{M}=3.766, \mathrm{SD}=.793)$ was more close to fair (4). The level of proficiency of the participants in reading $(\mathrm{M}=3.247, \mathrm{SD}=.652)$ was better the students' level of proficiency in writing ( $\mathrm{M}$ $=3.766, \mathrm{SD}=.793)$. The means of level of proficiency in language skills or components of the participants were between good and fair. The result of the students' level of proficiency in writing in this study agrees with the result of participants' level in writing in Solak's (2012) study, but the results of participants' level in listening and reading in Solak's (2012) study are better than the results of students' level of proficiency in listening and reading in this study. The results of the students' level of proficiency in language skills in this study disagree with the results of level of proficiency in language skills in Alsamadani's (2017) study. The differences between the results in this study and the results in Solak's (2012) study and Alsamadani's (2017) study may be the different participants.

For Question 2, from Table 2, we can know that the students rank the language skills (listening and speaking) as the most important language skills in all the five language skills and components. Chinese students' level of language skills (listening and speaking) are just so-so, students need to listen to ESP instructor in ESP classes and speak in English to express their ideas and answer questions in ESP classes, therefore they rank the language skills (listening and speaking) as the first order. The results of ranking the importance in language skills (listening, speaking, reading, writing and grammar) in this study disagree 
with that in Alsamadani's (2017) study.

For question 3, from Table 3, we can know that the language skills (listening, speaking, reading and writing) are emphasized by the chemical engineering and technology undergraduate students. The participants think the listening skills (understanding instructions and following question/answer sessions), the speaking skill (answering the questions), the reading skill (reading field-related textbooks) and the writing skill (taking notes in lectures) as more important activity or task in ESP classes. Students need the listening skills to understand instructions to gain the knowledge in ESP and need "follow question/answer sessions" to follow the instructor in ESP classes. And students need use the speaking skill (answering the questions) to answer the questions from the instructor and others students to express their ideas in ESP classes. Also students need read "field-related textbooks" to obtain the major knowledge and make notes in a short time in ESP classes. The results in this study disagree with that in Alsamadani's (2017) study. The students in this study who are first-year chemical engineering and technology students have studied a few major courses, and they just know some needs in ESP classes. The students in Alsamadani's (2017) study who are second-year engineering students majoring in industrial engineering and civil engineering at Umm Al-Qura University (Al-Lith, andAl-Qunfudah) have studied more major courses, they know what they need in ESP classes.

For question 4, we gain positive responses from the interview students on their needs in ESP classes. Forty eight students (80\% of 60 students) said that ESP would be better for them to improve their English learning and major study. Thirty two students (53.3\% of 60 students) thought the language skill (reading) as the most important language skill. General English, usually, is not involved in students' major knowledge and is seldom used for their occupation. However, ESP is involved in students' major knowledge and can be used for their occupation. The chemical engineering and technology undergraduate students need use ESP knowledge in target situations such as reading ESP books, writing academic papers. The chemical engineering and technology undergraduate students can combine English learning and major study, which will be better for their English learning and major study.

\section{Limitations and Suggestions for Further Research}

Though the present study has investigated a survey of there are still some limitations in the study.

Firstly, only 80 non-English-majored undergraduate students as the participants from one university are in this study. More participants are needed in further research.

Secondly, the instruments used in this study to investigate the chemical engineering and technology undergraduate students are questionnaires and interviews. The study would be much better, if it were combined with other instruments such as classroom observation, interviews with major instructors. More 
instruments should be used in investigating in the further research.

Finally, participants in this study were the non-English-majored undergraduate students in only one university. The study will be better if more participants from other universities can be participated in this study.

Despite of the restraints of the study, we hope that it can offer some guidelines for further research on needs analysis in ESP. The findings in this study could be provided as implications for course designers and recommendations for future studies.

\section{Conclusion}

English for Specific Purposes (ESP) combines English learning and academic study or occupational applications for learners. ESP courses are taught in more and more universities (such as Fudan University, Shanghai Jiaotong University). ESP courses are needed by students in common local university. Needs analysis is a basic step for ESP classes, such as course design, course arrangement. This study wanted to investigate first-year non-English-majored students' needs information in ESP. 80 first-year non-English-majored undergraduate students majored chemical engineering and technology from Yangtze university as volunteer participates were in this study to answer the questionnaires and interviewed about their needs in ESP. The results showed that: 1) The chemical engineering and technology undergraduate students' level of proficiency in the language skills was medium; 2) The participants ranked the language skills (listening and speaking) as the first important language skills; 3) Understanding instructions, following question/answer sessions, answering the questions, reading field-related textbooks, instructions for assignments, taking notes in lectures were more emphasized by the students in ESP classes; 4) The students had positive responses on their needs in ESP. We will make more researches on students' needs analysis in ESP classes, such as ESP courses planning, ESP courses textbooks choice, ESP exams in the future.

\section{Conflicts of Interest}

The authors declare no conflicts of interest regarding the publication of this paper.

\section{References}

Al-Otibi, A. M. (1994). Identifying the English Communication Needs of Kuwaiti Student Soldiers at the Military Institute in Kuwait. Unpublished Ph.D Thesis. UK: Cardiff University College.

Alsamadani, H. A. (2017). Needs Analysis in ESP Context: Saudi Engineering Students as a Case Study. Advances in Language and Literary Studies, 8, 58-68. https://doi.org/10.7575/aiac.alls.v.8n.6p.58

Brindley, G. (1989). The Role of Needs Analysis in Adult ESL Programme Design. In R. Johnson (Ed.), The Second Language Curriculum (pp. 43-78). Cambridge: Cambridge University Press. 
Dudley-Evans, T., \& ST John, M. J. (1998). Developments in English for Specific Purposes. Cambridge: Cambridge University Press.

Eslami, Z. R. (2010). Teachers' Voice vs. Students' Voice: A Needs Analysis Approach to English for Academic Purposes (EAP) in Iran. English Language Teaching, 3, 3-11. https://doi.org/10.5539/elt.v3n1p3

Hutchinson, T., \& Waters, A. (1987). English for Specific Purposes. New York: Cambridge University Press. https://doi.org/10.1017/CBO9780511733031

Jordan, R. R. (1997). English for Academic Purposes: A Guide and Resources Book for Teachers. London, UK: Cambridge University Press. https://doi.org/10.1017/CBO9780511733062

Li, J. (2014). Needs Analysis of Business English Undergraduates and the Implications to Business English Curriculum Design. Advances in Language and Literary Studies, 5, 33-37.

Luo, N., \& Chen, C. M. (2012). EAP Needs Analysis of Graduate Students of Science and Technology from the Mentors' Perspective. Contemporary Foreign Languages Studies, 5, 38-42.

Mohammed, S. A. H. (2016). Investigating the Application of Needs Analysis on EAP Business Administration Materials. English Language Teaching, 9, 74-79. https://doi.org/10.5539/elt.v9n3p74

Mohammed, A. S. E., \& Nur, H. S. M. (2018). Needs Analysis in English for Academic Purposes: The Case of Teaching Assistants at the University of Khartoum. HOW, 25, 49-68. https://doi.org/10.19183/how.25.2.409

Nafissi, Z., Rezaeipanah, F., \& Monsefi, R. (2017). Pre and Post Test Evaluations of Students in the Needs-AnalysisBased EAP Course at Undergraduate Level. Advances in Language and Literary Studies, 8, 207-214. https://doi.org/10.7575/aiac.alls.v.8n.1p.207

Rahman, M. (2015). English for Specific Purposes (ESP): A Holistic Review. Universal Journal of Educational Research, 3, 24-31.

Robinson, P. (1991). ESP Today: A Practitioner's Guide. New York: Prentice Hall.

Solak, E. (2012). A Study of Needs Analysis at Turkish Gendarmerie in Terms of English for Specific Purposes. The Journal of Language and Linguistic Studies, 8, 48-63.

Strevens, P. (1980). Teaching English as an International Language. Oxford: Pergamon Press Ltd.

Wang, Y. (2014). Postgraduates' Writing Teaching Model in English for Academic Purposes Based on Needs Analysis. Journal of Shenyang Normal University (Social Science Edition), 38, 127-129.

West, R. (1994). Needs Analysis in Language Teaching. Language Teaching, 27, 1-19. https://doi.org/10.1017/S0261444800007527

Ye, X. (2018). The Need Analysis of English for Students in International Trade Major and the Proposed Strategies-A Case Study in Two Application-Oriented Universities of Fujian Province. Journal of Southwest Jiaotong University (Social Sciences), 19, 9-17.

Yu, Z. G., \& Fu, L. P. (2015). Demand Analyzing and Course Setting of English for Academic Purpose of Postgraduates from Science and Engineering Disciplines. College English Teaching and Research, 78, 70-75.

Zhen, C. H., Cao, F. L., Guo, S. F., Zhang, H. Y., \& Yang, S. S. (2015). EGAP Need of Graduate Students in Medical Universities. Journal of Bengbu Medical College, 40, 814-816. 


\section{Appendix}

Students' structured Questionnaire

\section{Background}

Name:

Age:

Field of study:

${ }^{*}$ What level of proficiency do you think you have in the following language skills or components?

$1=$ Excellent $2=$ very good 3 = good $4=$ fair $5=$ poor

1. Listening

2. Speaking

3. Reading

4. Writing

\section{Language Needs}

${ }^{\star}$ Rank the following according to their importance. Circle the most appropriate choice.

$1=$ very important $\quad 2=$ important $3=$ not important $4=$ not applicable 5 $=$ applicable

5. How important is listening skill?

$\begin{array}{lllll}1 & 2 & 3 & 4 & 5\end{array}$

6. How important is speaking skill?

$\begin{array}{lllll}1 & 2 & 3 & 4 & 5\end{array}$

7. How important is reading skill?

$\begin{array}{lllll}1 & 2 & 3 & 4 & 5\end{array}$

8. How important is writing skill?

$\begin{array}{lllll}1 & 2 & 3 & 4 & 5\end{array}$

9. How important is grammar?

$\begin{array}{lllll}1 & 2 & 3 & 4 & 5\end{array}$

Listening

10. Listening to lectures

$\begin{array}{lllll}1 & 2 & 3 & 4 & 5\end{array}$

11. Understanding instructions

$\begin{array}{lllll}1 & 2 & 3 & 4 & 5\end{array}$

12. Following question/answer sessions

$\begin{array}{lllll}1 & 2 & 3 & 4 & 5\end{array}$

13. Understanding power point presentations

$\begin{array}{lllll}1 & 2 & 3 & 4 & 5\end{array}$ Speaking

14. Asking questions

15. Participating in discussions

$\begin{array}{lllll}1 & 2 & 3 & 4 & 5\end{array}$

16. Answering the questions

$\begin{array}{lllll}1 & 2 & 3 & 4 & 5\end{array}$

17. Giving oral presentations

$\begin{array}{lllll}1 & 2 & 3 & 4 & 5\end{array}$

18. Interacting with specialists in your field of stud

$\begin{array}{lllll}1 & 2 & 3 & 4 & 5\end{array}$

Reading

19. Field-related textbooks

$\begin{array}{lllll}1 & 2 & 3 & 4 & 5\end{array}$

20. Articles in journals

$\begin{array}{lllll}1 & 2 & 3 & 4 & 5\end{array}$

21. Handouts given by teachers

$\begin{array}{lllll}1 & 2 & 3 & 4 & 5\end{array}$

22. Instructions for assignments

$\begin{array}{lllll}1 & 2 & 3 & 4 & 5\end{array}$

Writing 
23. Taking notes in lectures

24. Class quizzes and exams

25. Assignments and homework

26. Field-specific report $\begin{array}{lllll}1 & 2 & 3 & 4 & 5\end{array}$

$\begin{array}{lllll}1 & 2 & 3 & 4 & 5\end{array}$

$\begin{array}{lllll}1 & 2 & 3 & 4 & 5\end{array}$

$\begin{array}{lllll}1 & 2 & 3 & 4 & 5\end{array}$ 